\title{
GAYA KEPEMIMPINAN KEPALA PUSKESMAS
}

\section{The Leadership Style Of Health Center Head}

\author{
IGG Heru Marwanto ${ }^{1}$ \\ ${ }^{1}$ Magister Ilmu Administrasi Universitas Kadiri
}

\begin{abstract}
Abstrak
Penelitian dalam studi ini dilatarbelakangi oleh berbagai cara yang dilakukan oleh pemimpin dalam menggerakkan bawahannya untuk mencapai tujuan organisasi pada akhirnya harus dapat pula menimbulkan kinerja dari para bawahannya. Secara tidak langsung kepemimpinan ikut menentukan terbentuknya kinerja pegawai. Semakin baik kepemimpinan seseorang terhadap bawahan, maka semakin tinggi pula kinerja bawahannya. Jenis penelitian ini adalah penelitian kualitatif, berdasarkan pembahasannya termasuk penelitian deskriptif. Hasil penelitiannya adalah 1) Implementasi perilaku kepala puskesmas dalam melakukan kepemimpinannya di Puskesmas Pandean Kecataman Dongko adalah mementingkan tugas ditunjukkan dengan puskesmas menerapkan azas musyawarah yang dilaksanakan pada saat apel maupun intern dengan programmer masing-masing kegiatan, meningkatkan disiplin waktu kerja untuk memenuhi target kinerja, kepala puskesmas mempunyai wewenang dari dinas kesehatan dan wajib dilakukan oleh bawahan atau staf, mementingkan hubungan kerja sama ditunjukkan dengan semua pegawai pada puskesmas Pandean diberikan tanggung jawab dalam menjalankan program-program kesehatan yang ada di puskesmas Pandean, dan mementingkan hasil yang dicapai yaitu dapat meningkatkan kinerja pegawai. 2) Faktor yang dominan dalam mengimplementasikan gaya kepemimpinan Kepala Puskesmas di Puskesmas Pandean Kecataman Dongko adalah tidak serta merta demokratis, namun situasional, Gaya kepemimpinan ini memberikan tanggungjawab dan wewenang kepada semua pihak, sehingga ikut terlibat aktif dalam organisasi, anggota diberi kesempatan untuk memberikan usul serta saran dan kritik demi kemajuan organisasi.
\end{abstract}

Kata Kunci: gaya kepemimpinan; Kepala Puskesmas; kinerja

\begin{abstract}
The various ways motivate the research in this thesis that the leader moves his subordinates to achieve the goals of the organization, in the end, must also be able to generate performance from his assistants. Indirectly leadership also determines the formation of employee performance. The better one's direction toward subordinates, the higher the performance of their subordinates. This type of research is qualitative research, based on the discussion including descriptive analysis. The results of the study were: 1) The implementation of the behavior of the head was concerned with the task indicated by the deliberation principles. That was carried out in the morning brainstorming and internally with the programmers of each activity. That increases the discipline of work time to meet the performance targets. Head Puskesmas has the authority of the health department and must be carried out by subordinates or staff, prioritizing the cooperation relationship shown by all employees at the Pandean health center given responsibility in carrying out health programs in the Pandean health center, and emphasizing the results achieved that can improve employee performance. 2) The dominant factor in implementing the leadership style of the Head of Community Health Center at Pandean Health Center Dongko District is not necessarily democratic, but situational, this leadership style gives responsibility and authority to all parties, so that they are actively involved in the organization, members are given the opportunity to provide suggestions and suggestions and criticism for the betterment of the organization.
\end{abstract}

Keywords: leadership style, puskesmas head, performance

\section{A. PENDAHULUAN}

Indeks Pembangunan Manusia (HDI= Human Developmant Indeks) terdapat tiga pilar utama yaitu pembangunan ekonomi, pembangunan pendidikan, dan pembangunan kesehatan. Pembangunan kesehatan merupakan bagian yang terpenting dan tidak terpisahkan atau terintegrasi dari pembangunan SDM. Hal ini karena tanpa adanya pembangunan kesehatan orang tak dapat hidup sehat, dan bila tak hidup 
sehat maka tak dapat berproduktif untuk menghasilkan pendapatan atau ekonomi yang baik, serta tak dapat memperbaiki pendidikannya.

Perkembangan kesehatan berorientasi pada peningkatan derajat kesehatan dan harapan hidup yang optimal. Dalam pencapaian tujuan pembangunan kesehatan, diperlukannya organisasi pelaksana kegiatan pembangunan bidang kesehatan dengan sumberdaya, baik sumberdaya manusianya maupun sumberdaya sarana dan prasarananya yang standar. Departemen kesehatan beserta jajarannya adalah sebagai penyelenggara pelayanan kesehatan.

Dalam mewujudkan tujuan pembangunan kesehatan departemen kesehatan juga harus bekerja sama dengan departemendepartemen lain sebagai kegiatan lintas sektoralnya, selain daripada lintas programnya, untuk memudahkan pencapaian programprogram kegiatannya.

Keberhasilan pembangunan kesehatan nasional saat ini tidak lepas dari upaya-upaya yang diselenggarakan oleh puskesmas. Puskesmas adalah unit pelaksana teknis dinas kesehatan kabupaten/kota yang menyelenggarakan pembangunan kesehatan di suatu wilayah kerja. Dalam melaksanakan tugas dan fungsi pembangunan derajat kesehatan bukanlah hal yang mudah, karena terjadi beberapa hambatan diantaranya adalah perilaku individu, masalah lingkungan, dan masalah penyediaan sarana dan prasarana pelayanan kesehatan. Selain itu juga masalah masih terbatasnya tenaga kesehatan dan kemampuan dalam melaksanakan manajemen kesehatan masyarakat.

Di antara semua masalah yang tersebut di atas, bidang kepemimpinan merupakan hal yang penting dalam suatu organisasi. Tanpa adanya kepemimpinan yang bagus pada diri kepala puskesmas dalam mencapai tujuan pembangunan kesehatan yaitu tercapainya derajat kesehatan yang optimal, sulit diwujudkan. Kemudian masih dijumpainya pelaksanaan program kesehatan yang direncanakan umumnya masih menggunakan kepentingan politik dan sekelompok tertentu. Masyarakat modern sekarang ini sangat membutuhkan kepemimpinan yang baik, yang mampu menuntun organisasi sesuai dengan azas-azas manajemen modern, sekaligus bersedia memberikan kesejahteraan dan kebahagian kepada bawahan dan masyarakat luas. Karena itu keberhasilan seorang pemimpin selain dapat dinilai dari produktivitas dan prestasinya, juga harus dinilai dari kebaikannya, dan tidak boleh melakukan penghisapan atau eksploitasi oleh manusia terhadap manusia.

Gaya kepemimpinan banyak mempengaruhi keberhasilan seorang pemimpin dalam mempengaruhi perilaku bawahannya. Istilah gaya adalah cara yang digunakan pemimpin dalam mempengaruhi para pengikutnya. Kepemimpinan di suatu organisasi perlu mengembangkan staf dan membangun iklim motivasi yang menghasilkan tingkat kinerja yang tinggi, maka pemimpin perlu memikirkan gaya kepemimpinannya. Gaya kepemimpinan merupakan norma perilaku yang digunakan oleh seseorang pada saat orang tersebut mencoba mempengaruhi perilaku orang lain seperti yang ia lihat, yang bertujuan menyelaraskan persepsi di antara orang akan mempengaruhi menjadi amat penting kedudukannya. Salah satu pendekatan yang dapat digunakan untuk mengetahui kesuksesan pemimpin ialah dengan mempelajari gayanya, karena gaya kepemimpinan banyak mempengaruhi keberhasilan seorang pemimpin dalam mempengaruhi perilaku bawahannya.

Berdasarkan survey awal yang dilakukan pada bulan Maret 2014 yang di Puskesmas kecamatan Dongko Kabupaten Trenggalek, di temukan permasalahan yaitu tentang kepemimpinan kepala puskesmas selama kurang lebih 1 tahun masih kurang dalam sistem perencanaan pelayanan publikmaupun program, pengawasan, pengambilan keputusan yang dilakukan oleh kepala puskesmas serta pengetahuan puskesmas dalam hal manajemen puskesmas.

Pemimpin yang mempunyai nilai tinggi pada dimensi pertimbangan menggambarkan suasana kerja yang saling mempercayai, menghormati gagasan bawahan, dan mempertimbangkan perasaan bawahan. Pemimpin dengan pertimbangan yang tinggi akan mendorong kerjasama yang baik dengan komunikasi dua arah. Sebaliknya pemimpin dengan nilai pertimbangan yang rendah menandakan bahwa mereka lebih tidak manusiawi ketika berurusan dengan bawahan. Nilai memprakarsai struktur yang tinggi menandakan bahwa pemimpin membuat struktur peran mereka dan peran bawahan menuju ke arah pencapaian sasaran. Mereka secara aktif terlibat dalam perencanaan kegiatan pekerjaan, mengkomunikasikan informasi yang tepat, serta menjadwalkan pekerjaan. 


\section{B. KERANGKA TEORI}

Gaya (style) kepemimpinan membawa diri sebagai pemimpin. Cara ia berlagak dan tampil dalam menggunakan kekuasaannya. Pemimpin itu mempunyai sifat, kebiasaan, tempramen, watak dan kepribadian sendiri yang unik dan khas sehingga tingkah laku dan gayanya yang membedakan dirinya dengan orang lain. Gaya atau style hidupnya pasti akan mewarnai perilaku dan tipe kepemimpinan. Gaya kepemimpinan merupakan suatu pola perilaku seorang pemimpin yang khas pada saat mempengaruhi anak buahnya, apa yang dipilih oleh pemimpin untuk dikerjakan, cara pemimpin bertindak dalam mempengaruhi anggota kelompok membentuk gaya kepemimpinannya. Secara teoritis telah banyak dikenal gaya kepemimpinan, namun gaya mana yang terbaik tidak mudah untuk ditentukan.

Ada Tiga gaya kepemimpinan yang pokok yaitu gaya kepemimpinan Otokratis, Demokratis, Laissez faire.
1. Gaya Kepemimpinan Otokratis
Gaya kepemimpinan Otokratis ini meletakkan seorang pemimpin sebagai sumber kebijakan. Pemimpin merupakan segala-galanya. Bawahan dipandang sebagai orang yang melaksanakan perintah. Oleh karena itu bawahan hanya menerima instruksi saja dan tidak diperkenankan membantah maupun mengeluarkan ide atau pendapat. Dalam posisi demikian anggota atau bawahan tidak terlibat dalam soal keorganisasian. Pada tipe kepemimpinan ini segala sesuatunya ditentukan oleh pemimpin sehingga keberhasilan organisasi terletak pada pemimpin.

Tipe ini menempatkan atau menunjukkan kekuasaan pada satu orang. Pemimpin bertindak sebagai penguasa tunggal. Kedudukan dan tugas anak buah semata-mata hanya sebagai pelaksana keputusan, perintah dan bahkan kehendak pemimpin. Pemimpin memandang dirinya lebih dalam segala hal, dibandingkan dengan bawahannya. Kemampuan bawahan selalu dipandang rendah, sehingga dianggap tidak mampu berbuat sesuatu tanpa diperintah.

Pemimpin yang otokrasi tidak menghendaki rapat-rapat atau musyawarah. Berkumpul atau rapat hanyalah berarti untuk menyampaikan instruksi-instruksi. Setiap perbedaan pendapat di antara anggota-anggota kelompoknya diartikan sebagai kepicikan, pembangkangan atau pelanggaran disiplin terhadap perintah atau instruksi yang telah ditetapkannya.

Kepemimpinan otokrasi bilamana melimpahkan wewenang tidak dapat lain dari wewenang melaksanakan instruksi, yang pada dasarnya tidak mengandung hak untuk menetapkan jenis dan cara melaksanakan instruksi, yang pada dasarnya tidak mengandung hak untuk menetapkan jenis dan cara melaksanakan pekerjaan. Dengan kata lain dalam kepemimpinan ini sebenarnya tidak terdapat pelimpahan wewenang pada bawahan. Wewenang sepenuhnya berada pada satu orang yang berkedudukan sebagai pucuk pimpinan. Bawahan hanya menerima pelimpahan tanggung jawab melaksanakan keputusan atasan dengan hak veto untuk menghentikan atau mengubah kegiatan yang sedang dilaksanakan setiap saat bila atasan mengangggap suatu kegiatan tidak sesuai dengan kehendaknya. Dengan demikian secara sederhana dapat dikatakan bahwa dalam suatu kegiatan tidak sesuai dengan kehendaknya. Kepemimpinan bentuk ini pelimpahan tanggung jawab tidak disertai pelimpahan wewenang.

2. Gaya Kepemimpinan Demokratis

Gaya kepemimpinan ini memberikan tanggungjawab dan wewenang kepada semua pihak, sehingga ikut terlibat aktif dalam organisasi, anggota diberi kesempatan untuk memberikan usul serta saran dan kritik demi kemajuan organisasi. Gaya kepemimpinan ini memandang bawahan sebagai bagian dari keseluruhan organisasinya, sehingga mendapat tempat sesuai dengan harkat dan martabatnya sebagai manusia. Pemimpin mempunyai tanggungjawab dan tugas untuk mengarahkan, mengontrol dan mengevaluasi serta mengkoordinasi.

Kepemimpinan gaya ini lebih berorientasi pada manusia dan memberikan bimbingan yang efisien pada bawahan. Dalam kepemimpinan ini setiap individu sebagai manusia diakui dan dihargai eksistensi dan perannya dalam memajukan dan mengembangkan lembaga. Dalam gaya kepemimpinan ini setiap kemauan, kehendak, kemampuan, buah pikiran, gagasan, pendapat, ide cerdas, minat dan perhatian dan lain-lain. Berbeda-beda pendapat antara individu, selalu dihargai dan disalurkan untuk kepentingan bersama.

Pemimpin yang demokratis menyadari kekuatan kelompok adalah keseluruhan dari kekuatan-kekuatan anggotanya. Kalau ia ingin memperkuat kelompoknya maka ia akan memperkuat setiap anggotanya. Dengan kata lain apabila ia ingin meningkatkan kualitas kelompoknya, maka ia akan meningkatkan kualitas setiap anggota kelompoknya. Karena itu dalam kepemimpinan demokratis prinsip utama ialah mengikutsertakan semua orang dalam penetapan dan penentuan strategi sebagai usaha pencapaian tujuan bersama. Setiap pengambilan 
keputusan selalu didasarkan pada musyawarah dan mufakat. Sedangkan prinsip lain yang tidak kalah pentingnya ialah prinsip-prinsip pembinaan terhadap anggota kelompok yang terus menerus agar meningkatkan kualitasnya. Di lingkungan lembaga-lembaga kesehatan, kepemimpinan demokratis merupakan bentuk yang paling serasi karena memungkinkan setiap personal berpartisipasi secara aktif dalam mengembangkan dan memajukan organisasi sebagai wadah yang mengemban misi pendewasaan anak-anak. Dengan kepemimpinan ini setiap saran dan pendapat sebagai pencerminan inisiatif dan kreatifitas, selalu dipertimbangkan bersama untuk diwujudkan demi kepentingan bersama.

3. Gaya Kepemimpinan Laissez faire

Gaya kepemimpinan ini pemimpin tidak memimpin, dia hanya membiarkan kelompoknya berbuat semaunya sendiri. Pemimpin tidak berpartisipasi sedikitpun dalam kegiatan kelompoknya. Semua pekerjaan dikerjakan oleh bawahannya. Dan pemimpin dalam hal ini sebagai simbol atau lambang lembaga. Kepemimpinannya dijalankan dengan memberikan kebebasan kepada semua anggota dalam menetapkan keputusan dan melaksanakannya menurut kehendak masingmasing.

Tipe kepemimpinannya ini merupakan kebalikan dari tipe kepemimpinan otoriter. Kepemimpinan dijalankan dengan memberikan kebebasan penuh pada orang-orang yang dipimpim dengan mengambil keputusan dan melakukan kegiatan menurut kehendak dan kepentingan masing-masing, baik secara perorangan maupun kelompok-kelompok kecil. Pemimpin hanya memfungsikan dirinya sebagai penasehat. Dengan demikian sepanjang orang yang dipimpin merasa mampu mengambil keputusan sendiri dan melaksanakannya sendiri pula, maka pemimpin tidak akan berfungsi. Kebebasan diberikan menurut kemauan orangorang yang dipimpin, tidak terarah sehingga perwujudan kerja menjadi simpang siur, dan wewenang menjadi tidak jelas dan tanggung jawab menjadi kacau.

Kepemimpinan Laissez Faire, pada dasarnya kurang tepat bila dilaksanakan secara murni di lingkungan pelayanan kesehatan. Dalam kepemimpinan ini setiap anggota kelompok bergerak sendiri-sendiri, sehingga semua aspek manajemen administratif tidak dapat diwujudkan dan dikembangkan. Pemimpin yang Laissez Faire menganggap bahwa guru-guru atau anggota kelompoknya adalah orang-orang yang sudah dewasa dan sudah matang. Jadi mereka dapat mengatur dan mengarahkan dirinya sendiri.
Tingkat keberhasilan organisasi atau lembaga yang dipimpin dengan gaya Laissez Faire semata-mata disebabkan karena kesadaran dan dedikasi beberapa anggota kelompok dan bukan karena pengaruh dari pemimpinnya. Di dalam tipe ini biasanya struktur organisasinya tidak jelas dan kabur. Segala kegiatan dilakukan tanpa rencana, yang terarah dan tanpa pengawasan dari pemimpin.

Faktor pemimpin dalam kepemimpinan tidak dapat dilepaskan dari faktor orang yang dipimpin, keduanya saling tergantung sehingga yang satu tidak mungkin ada tanpa yang lain. Kepemimpinan merupakan proses interaksi antara kedua belah pihak yakni pemimpin dan yang dipimpin dalam relasi manusia (human relationship).

Peranan kepemimpinan akan menjadi penting dan dibutuhkan untuk menyelaraskan berbagai macam kebutuhan dan juga untuk menciptakan situasi kerja yang kondusif. Disamping itu dapat mendorong para pegawai untuk berprilaku sesuai dengan tujuan organisasi yang ditetapkan. Meskipun pimpinan telah membina hubungan komunikasi yang baik dengan para karyawan, namun tidak serta merta terjadi komunikasi yang baik begitu saja. Komunikasi yang terjalin selama ini pada Dinas Pendapatan Daerah Kota Trenggalek belum dapat mendorong para karyawan untuk bekerja sungguh-sungguh tentu saja ini mengakibatkan efektivitas pelayanannya belum optimal. Selain itu pimpinan bersama jajarannya jarang melakukan evaluasi apakah kinerja karyawannya sudah bagus, pimpinan jarang turun kebawah, dan menanyakan langsung hambatan-hambatan apa yang menyebabkan kinerja karyawan belum sesuai yang ditetapkan.

Kepemimpinan dalam usaha mencapai tujuan organisasi sehingga dapat dikatakan bahwa maju mundurnya suatu organisasi/lembaga banyak ditentukan oleh kualitas seorang pemimpin. Sedangkan menurut Mujamil Qomar adalah kegiatan atau proses memimpin dalam mengendalikan suatu organisasi untuk mencapai tujuan tertentu. Kepemimpinan merupakan kemampuan seseorang dalam mengerakkan, mengarahkan sekaligus mempengaruhi pola pikir, cara kerja setiap anggota agar bersikap mandiri dalam bekerja terutama dalam pengambilan keputusan untuk kepentingan percepatan pencapaian tujuan yang telah ditetapkan.

Kinerja pada dasarnya merupakan tolok ukur keberhasilan seseorang dalam melakukan suatu pekerjaan atau dalam melaksanakan tugastugas yang menjadi tanggung jawabnya. Maier sebagaimana yang dikutip oleh As'ad 
menjelaskan bahwa kinerja merupakan kesuksesan seseorang dalam melaksanakan suatu pekerjaan. Pemberdayaan kinerja karyawan dilakukan dengan memberi kesempatan kepada para karyawan untuk meningkatkan profesinya, dan mendorong keterlibatan seluruh karyawan dalam berbagai kegiatan yang menunjang program pemerintahan daerah kabupaten Trenggalek.

Salah satu hal yang harus diperhatikan dalam pelaksanaan pekerjaan yaitu tercapainya kinerja yang baik, sesuai dengan standar kinerja yang diterapkan dan yang diinginkan organisasi, dan sesuai dengan visi dan misi organisasi. Namun, agar semua karyawan dapat mewujudkan kinerja yang diinginkan, banyak faktor yang mungkin mempengaruhi bagi karyawan seperti gaya kepemimpinan komunikasi yang baik dan lain sebagainya. Berkaitan dengan hal tersebut, dalam penelitian ini akan membahas dua faktor yang diidentifikasi yaitu gaya kepemimpinan yang mungkin mempengaruhi kinerja dari karyawan.

Dari berbagai cara yang dilakukan oleh pemimpin dalam menggerakkan bawahannya untuk mencapai tujuan organisasi pada akhirnya harus dapat pula menimbulkan kinerja dari para bawahannya. Secara tidak langsung kepemimpinan ikut menentukan terbentuknya kinerja pegawai. Semakin baik kepemimpinan seseorang terhadap bawahan, maka semakin tinggi pula kinerja bawahannya.

Peranan seorang pemimpin penting untuk mencapai tujuan organisasi yang diinginkan termasuk organisasi pemerintahan di kota Trenggalek terutama berkaitan dengan kinerja pegawai dalam melaksanakan pekerjaannya. Kinerja pegawai merupakan hasil kerja yang dapat dicapai seseorang atau sekelompok orang dalam suatu organisasi sesuai wewenang dan tanggung jawab masingmasing dalam rangka mewujudkan tujuan organisasi.

Faktor pertama yang diidentifikasikan mempengaruhi kinerja karyawan adalah kepemimpinan. Pemimpin dengan gaya kepemimpinannya menentukan strategi organisasi baik jangka panjang maupun jangka pendek. Kepemimpinan merupakan pengarahan langsung dan tidak langsung kepada karyawan untuk melakukan pekerjaan. Kepemimpinan dalam konteks penelitian ini yang akan dikaji adalah mengenai gaya kepemimpinan (leadership style) yaitu kepemimpinan transformasional dan kepemimpinan transaksional. Faktor kepemimpinan ini mempunyai berpengaruh langsung terhadap strategi organisasi yaitu pada saat merencanakan (membuat kebijakan dan mengambil keputusan), implementasi (pelaksanaan kerja), dan evaluasi (kinerja organisasi secara keseluruhan).

Menurut Robbin kepemimpinan merupakan kemampuan untuk mempengaruhi kelompok menuju pencapaian sasaran. Gaya kepemimpinan dapat didefinisikan sebagai pola tingkah laku yang dirancang untuk mengintegrasikan tujuan organisasi dengan tujuan individu untuk mencapai suatu tujuan tertentu. Hubungan antara kinerja karyawan dan gaya kepemimpinan seorang manajer berpengaruh dalam pencapaian tujuan suatu organisasi. Mengenai gaya kepemimpinan pada organisasi, setiap pemimpin pada masingmasing organisasi mempunyai gaya kepemimpinan yang berbeda antara yang satu dengan yang lain baik sektor publik maupun swasta. Bentuk gaya kepemimpinan yang diterapkan dalam suatu organisasi mungkin dapat mempengaruhi kinerja setiap karyawan. Adanya gaya kepemimpinan yang sesuai dengan situasi dan kondisi organisasi maka karyawan akan lebih bersemangat dalam menjalankan tugas dan kewajibannya dan mempunyai harapan terpenuhinya kebutuhan.

Hasil penelitian yang dilakukan oleh Firdian Syah (2002), tentang Kemampuan Manajerial Kepala Puskesmas Terhadap Kepuasan Kerja Staf Puskesmas di Puskesmas Kota Sabang Propinsi Sumatera Utara didapat gambaran bahwa: (1) $24 \%$ fungsi pengorganisasian dalam kemampuan kemanajerialan kepala puskesmas tidak berjalan dengan baik, (2) 31,2\% fungsi pelaksanaan dalam kemampuan kemanajerialan kepala puskesmas tidak berjalan dengan baik.

\section{METODE PENELITIAN}

Penelitian ini jika dilihat dari lokasi sumber datanya termasuk kategori penelitian lapangan (field research).Penelitian lapangan adalah untuk mencari di mana peristiwaperistiwa yang menjadi objek penelitian berlangsung, sehingga mendapatkan informasi langsungdan terbaru tentang masalah yang berkenaan, sekaligus sebagai cross checking terhadap bahan-bahan yang telah ada. Ditinjau dari segi sifat-sifat data maka termasuk dalam penelitian Kualitatif yaitu penelitian yang bermaksud untuk memahami fenomena tentang apa yang dialami oleh subjek penelitian misalnya perilaku, persepsi, motivasi, tindakan dan lainlain secara holistik, dan dengan cara deskripsi dalam bentuk kata-kata dan bahasa, pada suatu konteks khusus yang alamiah dan dengan me,manfaatkan berbagai metode alamiah. 
Jika di tinjau dari sudut kemampuan atau kemungkinan penelitian dapat memberikan informasi atau penjelasan, maka penelitian ini termasuk penelitian termasuk penelitian deskriptif. Penelitian deskriptif merupakan penelitian yang berusaha mendeskriptifkan mengenai unit sosial tertentu yang meliputi individu, kelompok, lembaga dan masyarakat. Dari segi pendekatan jenis penelitian ini adalah berupa penelitian deskriptif kualitatif, oleh sebab itu pendekatan yang dilakukan adalah melalui pendekatan kualitatif. Maksudnya adalah dalam penelitian pendidikan kualitatif data yang dikumpulkan bukan berupa angka-angka, melainkan data tersebut mungkin berasal dan naskah wawancara, catatan lapangan, dokumen pribadi, cacatan memo dan dokumen resmi lainya. Sehingga yang menjadi tujuan dalam penelitian diskriptif kualitatif ini adalah ingin menggambarkan dan menginterprestasikan objek dengan apa adanya.

Penelitian kualitatif naturalistik peneliti gunakan karena obyek yang diteliti berlangsung dalam latar yang wajar dan bertujuan untuk mengetahui, memahami, dan menghayati dengan seksama dan secara lebih mendalam tentang bagaimana gaya kepemimpinan kepala puskesmas di Puskesmas Pandean Kecataman Dongko Trenggalek.

Pengumpulan data dalam penelitian ini dilakukan dengan observasi partisipan, wawancara mendalam dan studi dokumentasi yang pelaksanaannya diuraikan sebagai berikut:

1. Observasi Partisipan(participant observation). Cara pengumpulan data berdasarkan observasi menggunakan mata, telinga, secara langsung tanpa melalui alat bantu yang berstandar. Observasi bisa juga disebut dengan istilah pengamatan. Observasi dilakukan untuk menggali data dari sumber data yang berupa peristiwa, tempat, benda, serta rekaman dan gambar. Dalam penelitian ini dilaksanakan dengan teknik (participant observation), yaitu dilakukan dengan cara penelitian melibatkan diri atau berinteraksi pada kegiatan yang dilakukan oleh subyek penelitian dalam lingkungannya, selain itu juga mengumpulkan data secara sistematik dalam bentuk catatan lapangan. Teknik inilah yang disebut teknik observasi partisipan. Dalam observasi partisipan, peneliti menggunakan buku catatan kecil. Buku catatan kecil diperlukan untuk mencatat hal-hal penting yang ditemui selama pengamatan. Ada tiga tahap observasi yang dilakuka dalam penelitian, yaitu observasi deskriptif (untuk mengetahui gambaran umum), observasi terfokus (untuk menemukan kategori-kategori), dan observasi selektif (mencari perbedaan di antara kategori-kategori).
Observasi peneliti lakukan, sebagaimana menurut Faisal, yang menyatakan bahwa observasi difokuskan pada situasi sosial, yaitu:

a. Gambaran keadaan tempat dan ruang tempat suatu sosial berlangsung.

b. Para pelaku pada suatu situasi sosial, termasuk karakteristik yang melekat pada mereka (seperti status, jenis kelamin, usia, dan sebagainya).

c. Kegiatan atau aktivitas yang berlangsung pada situasi sosial.

d. Tingkah laku para pelaku dalam proses berlangsungnya aktifitas atau kegiatan di suatu situasi sosial (tindakan-tindakan).

e. Peristiwa yang berlangsung di suatu situasi sosial (perangkat aktifitas atau kegiatan yang saling berhubungan).

f. Waktu berlangsungnya peristiwa, kegiatan, dan tindakan di suatu situasi sosial.

g. Ekspresi perasaan yang tampak pada para pelaku di suatu situasi sosial.

Demikian beberapa peristiwa yang harus diobservasi. Tanpa melakukan observasi tersebut, maka musthail penelitian ini bisa berjalan dan berhasil dengan baik dan memuaskan. Dalam penelitian ini peneliti melakukan observasi partisipan tahap pertama, yaitu dimulai dari observasi deskriptif (descriptive observation) secara luas dengan melukiskan secara umum situasi sosial yang terjadi pada lembaga yang menjadi subjek penelitian, yaitu Puskesmas Pandean Kecataman Dongko Trenggalek. Tahap berikutnya dilakukan terfokus (focused observation) untuk menemukan kategori-kategori strategi kepemimpinan kepala puskesmas dalam meningkatkan kinerja pegawai di Puskesmas Pandean Kecataman Dongko Trenggalek. Tahap akhir setelah dilakukan analisis dan observasi yang berulang-ulang diadakan penyempitan lagi dengan melakukan observasi selektif (selective observation) dengan mencari perbedaan di antara kategori-kategori. Semua hasil pengamatan selanjutnya dicatat sebagai pengamatan lapangan (field note), yang selanjutnya dilakukan refleksi.

2. Wawancara Mendalam(Indepth Interview)

Sumber data yang sangat penting dalam penelitian kualitatif adalah yang berupa manusia yang dalam posisi sebagai narasumber atau informan. Untuk mengumpulkan informasi dari sumber data ini diperlukan teknik wawancara. Wawancara adalah percakapan denga maksud tertentu. Percakapan dilakuka oleh dua pihak, yaitu pewawancara (interviewer) yang mengajukan pertanyaan dan terwawancara (interviewee) yang memberikan jawaban atas pertanyaan itu. Dalam wawancara, peneliti 
menggunakan wawancara terbuka yang dimana pihak subyek atau terwawancara mengetahui bahwa mereka sedang diwawancarai dan mengetahui apa maksud dan tujuan wawancara yang sedang dilakukan oleh peneliti.

Peneliti juga mengadakan wawancara mendalam adalah percakapan antara dua orang dengan maksud tertentu dalam hal ini antara peneliti dengan informan, dimana percakapan yang di maksud tidak sekedar menjawab pertanyaan sebagai istilah percakapan dalam pengertian sehari-hari, melainkan suatu percakapan yang mendalam untuk mendalami pengalaman dan makna dari pengalaman tersebut.

Teknik yang digunakan dalam wawancara adalah wawancara tidak terstruktur (unstandarized interview) yang dilakukan tanpa menyusun suatu daftar pertanyaan yang ketat. Selanjutnya wawancara unstandarized ini dikembangkan menjadi tiga teknik, yaitu: 1) Wawancara tidak terstruktur (unstructured interview atau passive interview), dengan wawancara ini bisa diperoleh data "emic" ; 2) Wawancara agak terstruktur (some what structured interview or active interview), dengan wawancara ini dapat diperoleh data "etic" ; 3) wawancara sambil lalu (casual interview).

\section{PEMBAHASAN}

\section{Implementasi Perilaku Kepala Puskesmas dalam Melakukan Kepemimpinannya di Puskesmas Pandean Kecataman Dongko}

Implementasi perilaku kepemimpinan otokratis kepala puskesmas dalam meningkatkan kinerja pegawai di Puskesmas Pandean Kecamatan Dongko ditunjukkan dengan puskesmas menerapkan azas musyawarah yang dilaksanakan pada saat apel maupun intern dengan programmer masing-masing kegiatan, meningkatkan disiplin waktu kerja untuk memenuhi target kinerja, kepala puskesmas mempunyai wewenang dari dinas kesehatan dan wajib dilakukan oleh bawahan atau staf.

Gaya kepemimpinan banyak mempengaruhi keberhasilan seorang pemimpin dalam mempengaruhi perilaku bawahannya. Istilah gaya adalah cara yang digunakan pemimpin dalam mempengaruhi para pengikutnya. Kepemimpinan di suatu organisasi perlu mengembangkan staf dan membangun iklim motivasi yang menghasilkan tingkat kinerja yang tinggi, maka pemimpin perlu memikirkan gaya kepemimpinannya. Gaya kepemimpinan merupakan norma perilaku yang digunakan oleh seseorang pada saat orang tersebut mencoba mempengaruhi perilaku orang lain seperti yang ia lihat, yang bertujuan menyelaraskan persepsi di antara orang akan mempengaruhi menjadi amat penting kedudukannya. Salah satu pendekatan yang dapat digunakan untuk mengetahui kesuksesan pemimpin ialah dengan mempelajari gayanya, karena gaya kepemimpinan banyak mempengaruhi keberhasilan seorang pemimpin dalam mempengaruhi perilaku bawahannya. Faktor pemimpin dalam kepemimpinan tidak dapat dilepaskan dari faktor orang yang dipimpin, keduanya saling tergantung sehingga yang satu tidak mungkin ada tanpa yang lain. Kepemimpinan merupakan proses interaksi antara kedua belah pihak yakni pemimpin dan yang dipimpin dalam relasi manusia (human relationship).

Hal ini sesuai menurut Ngalim Purwanto Pemimpin yang otokrasi tidak menghendaki rapat-rapat atau musyawarah. Berkumpul atau rapat hanyalah berarti untuk menyampaikan instruksi-instruksi. Setiap perbedaan pendapat di antara anggota-anggota kelompoknya diartikan sebagai kepicikan, pembangkangan atau pelanggaran disiplin terhadap perintah atau instruksi yang telah ditetapkannya. Gaya kepemimpinan Otokratis ini meletakkan seorang pemimpin sebagai sumber kebijakan. Pemimpin merupakan segala-galanya. Bawahan dipandang sebagai orang yang melaksanakan perintah. Oleh karena itu bawahan hanya menerima instruksi saja dan tidak diperkenankan membantah maupun mengeluarkan ide atau pendapat. Dalam posisi demikian anggota atau bawahan tidak terlibat dalam soal keorganisasian. Pada tipe kepemimpinan ini segala sesuatunya ditentukan oleh pemimpin sehingga keberhasilan organisasi terletak pada pemimpin. Tipe ini menempatkan atau menunjukkan kekuasaan pada satu orang. Pemimpin bertindak sebagai penguasa tunggal. Kedudukan dan tugas anak buah semata-mata hanya sebagai pelaksana keputusan, perintah dan bahkan kehendak pemimpin. Pemimpin memandang dirinya lebih dalam segala hal, dibandingkan dengan bawahannya. Kemampuan bawahan selalu dipandang rendah, sehingga dianggap tidak mampu berbuat sesuatu tanpa diperintah.

Kepemimpinan otokrasi bilamana melimpahkan wewenang tidak dapat lain dari wewenang melaksanakan instruksi, yang pada dasarnya tidak mengandung hak untuk menetapkan jenis dan cara melaksanakan instruksi, yang pada dasarnya tidak mengandung hak untuk menetapkan jenis dan cara 
melaksanakan pekerjaan. Dengan kata lain dalam kepemimpinan ini sebenarnya tidak terdapat pelimpahan wewenang pada bawahan. Wewenang sepenuhnya berada pada satu orang yang berkedudukan sebagai pucuk pimpinan. Bawahan hanya menerima pelimpahan tanggung jawab melaksanakan keputusan atasan dengan hak veto untuk menghentikan atau mengubah kegiatan yang sedang dilaksanakan setiap saat bila atasan mengangggap suatu kegiatan tidak sesuai dengan kehendaknya. Dengan demikian secara sederhana dapat dikatakan bahwa dalam suatu kegiatan tidak sesuai dengan kehendaknya. Kepemimpinan bentuk ini pelimpahan tanggung jawab tidak disertai pelimpahan wewenang.

Kecenderungan perilaku kepemimpinan demokratis kepala puskesmas dalam meningkatkan kinerja pegawai di Puskesmas Pandean Kecamatan Dongko ditunjukkan dengan semua pegawai pada PKM Pandean diberikan tanggung jawab dalam menjalankan programprogram kesehatan yang ada di PKM Pandean, Atasan memberikan wewenang dan tanggung jawab kepada bawahan berdasarkan tugas pokok dan fungsi masing-masing. Bawahan sepenuhnya diberikan kebebasan mengutarakan pendapat dan saran dalam memajukan puskesmas Pandean. Gaya kepemimpinan demokratis digunakan untuk mensinkronkan kinerja bawahan dan atasan dengan cara musyawarah untuk mencapai kesepakatan bersama, 4) pemimpin benar-benar bertanggung jawab atas tercapainya suatu tujuan yang mendorong untuk perkembangan dan kualitas pelayanan berorientasi pada pelayanan dan membawa energy positif.

Hal ini sesuai menurut Muwahid Sulhan bahwa Pemimpin yang demokratis menyadari kekuatan kelompok adalah keseluruhan dari kekuatan-kekuatan anggotanya. Kalau ia ingin memperkuat kelompoknya maka ia akan memperkuat setiap anggotanya. Dengan kata lain apabila ia ingin meningkatkan kualitas kelompoknya, maka ia akan meningkatkan kualitas setiap anggota kelompoknya. Karena itu dalam kepemimpinan demokratis prinsip utama ialah mengikutsertakan semua orang dalam penetapan dan penentuan strategi sebagai usaha pencapaian tujuan bersama. Setiap pengambilan keputusan selalu didasarkan pada musyawarah dan mufakat. Sedangkan prinsip lain yang tidak kalah pentingnya ialah prinsip-prinsip pembinaan terhadap anggota kelompok yang terus menerus agar meningkatkan kualitasnya. Di lingkungan lembaga-lembaga kesehatan, kepemimpinan demokratis merupakan bentuk yang paling serasi karena memungkinkan setiap personal berpartisipasi secara aktif dalam mengembangkan dan memajukan organisasi sebagai wadah yang mengemban misi pendewasaan anak-anak. Dengan kepemimpinan ini setiap saran dan pendapat sebagai pencerminan inisiatif dan kreatifitas, selalu dipertimbangkan bersama untuk diwujudkan demi kepentingan bersama.

Gaya kepemimpinan ini memberikan tanggungjawab dan wewenang kepada semua pihak, sehingga ikut terlibat aktif dalam organisasi, anggota diberi kesempatan untuk memberikan usul serta saran dan kritik demi kemajuan organisasi. Gaya kepemimpinan ini memandang bawahan sebagai bagian dari keseluruhan organisasinya, sehingga mendapat tempat sesuai dengan harkat dan martabatnya sebagai manusia. Pemimpin mempunyai tanggungjawab dan tugas untuk mengarahkan, mengontrol dan mengevaluasi serta mengkoordinasi.

Kepemimpinan gaya ini lebih berorientasi pada manusia dan memberikan bimbingan yang efisien pada bawahan. Dalam kepemimpinan ini setiap individu sebagai manusia diakui dan dihargai eksistensi dan perannya dalam memajukan dan mengembangkan lembaga. Dalam gaya kepemimpinan ini setiap kemauan, kehendak, kemampuan, buah pikiran, gagasan, pendapat, ide cerdas, minat dan perhatian dan lain-lain. Berbeda-beda pendapat antara individu, selalu dihargai dan disalurkan untuk kepentingan bersama.

\section{Faktor yang Dominan dalam Mengimplementasikan Gaya Kepemimpinan Kepala Puskesmas di Puskesmas Pandean Kecataman Dongko}

Gaya kepemimpinan yang dominan diperlihatkan oleh Kepala Puskesmas dalam aktivitas kepemimpinannya di Puskesmas Pandean Kecataman Dongko adalah demokratis, Gaya kepemimpinan ini memberikan tanggungjawab dan wewenang kepada semua pihak, sehingga ikut terlibat aktif dalam organisasi, anggota diberi kesempatan untuk memberikan usul serta saran dan kritik demi kemajuan organisasi. Gaya kepemimpinan ini memandang bawahan sebagai bagian dari keseluruhan organisasinya, sehingga mendapat tempat sesuai dengan harkat dan martabatnya sebagai manusia. Pemimpin mempunyai tanggungjawab dan tugas untuk mengarahkan, mengontrol dan mengevaluasi serta mengkoordinasi.

Kepemimpinan dalam usaha mencapai tujuan organisasi sehingga dapat dikatakan 
bahwa maju mundurnya suatu organisasi/lembaga banyak ditentukan oleh kualitas seorang pemimpin. Sedangkan menurut Mujamil Qomar adalah kegiatan atau proses memimpin dalam mengendalikan suatu organisasi untuk mencapai tujuan tertentu. Kepemimpinan merupakan kemampuan seseorang dalam mengerakkan, mengarahkan sekaligus mempengaruhi pola pikir, cara kerja setiap anggota agar bersikap mandiri dalam bekerja terutama dalam pengambilan keputusan untuk kepentingan percepatan pencapaian tujuan yang telah ditetapkan.

Hal ini sesuai menurut Muwahid Sulhan bahwa pemimpin yang demokratis menyadari kekuatan kelompok adalah keseluruhan dari kekuatan-kekuatan anggotanya. Kalau ia ingin memperkuat kelompoknya maka ia akan memperkuat setiap anggotanya. Dengan kata lain apabila ia ingin meningkatkan kualitas kelompoknya, maka ia akan meningkatkan kualitas setiap anggota kelompoknya. Karena itu dalam kepemimpinan demokratis prinsip utama ialah mengikutsertakan semua orang dalam penetapan dan penentuan strategi sebagai usaha pencapaian tujuan bersama. Setiap pengambilan keputusan selalu didasarkan pada musyawarah dan mufakat. Sedangkan prinsip lain yang tidak kalah pentingnya ialah prinsip-prinsip pembinaan terhadap anggota kelompok yang terus menerus agar meningkatkan kualitasnya. Gaya kepemimpinan ini memberikan tanggungjawab dan wewenang kepada semua pihak, sehingga ikut terlibat aktif dalam organisasi, anggota diberi kesempatan untuk memberikan usul serta saran dan kritik demi kemajuan organisasi. Gaya kepemimpinan ini memandang bawahan sebagai bagian dari keseluruhan organisasinya, sehingga mendapat tempat sesuai dengan harkat dan martabatnya sebagai manusia. Pemimpin mempunyai tanggungjawab dan tugas untuk mengarahkan, mengontrol dan mengevaluasi serta mengkoordinasi.

\section{E. KESIMPULAN DAN REKOMENDASI}

Implementasi Perilaku Kepala Puskesmas dalam Melakukan Kepemimpinannya di Puskesmas Pandean Kecataman Dongko adalah mementingkan tugas ditunjukkan dengan puskesmas menerapkan azas musyawarah yang dilaksanakan pada saat apel maupun intern dengan programmer masing-masing kegiatan, meningkatkan disiplin waktu kerja untuk memenuhi target kinerja, kepala puskesmas mempunyai wewenang dari dinas kesehatan dan wajib dilakukan oleh bawahan atau staf, mementingkan hubungan kerja sama ditunjukkan dengan semua pegawai pada puskesmas Pandean diberikan tanggung jawab dalam menjalankan program-program kesehatan yang ada di puskesmas Pandean, dan mementingkan hasil yang dicapai yaitu dapat meningkatkan kinerja pegawai. Dengan demikian terlihat bahwa kecenderungan perilaku kepala puskesmas dalam aktivitas kepemimpinan dengan bawahannya semakin baik, sehingga kinerja bawahannya sangat baik.

Faktor yang Dominan dalam Mengimplementasikan Gaya Kepemimpinan Kepala Puskesmas di Puskesmas Pandean Kecataman Dongko adalah tidak serta merta demokratis, namun situasional, Gaya kepemimpinan ini memberikan tanggungjawab dan wewenang kepada semua pihak, sehingga ikut terlibat aktif dalam organisasi, anggota diberi kesempatan untuk memberikan usul serta saran dan kritik demi kemajuan organisasi.

\section{F. REFERENSI}

James P. Spradley, Participant Observation, New York: Holt, Rinehard and Winston, 1980

Kartini Kartono, Pemimpin dan Kepemimpinan, Jakarta: Raja Grafindo Persada, 2005

Lexy J. Moleong, Metodologi Penelitian Kualitatif, Bandung: Remaja Rosdakarya, 2006

Lukman Hakim, Pengaruh Gaya Kepemimpinan Terhadap Kinerja Pegawai Negeri Sipil Melalui Motivasi Pada Dinas Perhubungan Kota Palembang, Jurnal Ilmiah, Volume III No.3, 2011

Muhammad As'ad, Psikologi Industri, Yogyakarta:Liberty, 1995

Mujamil Qomar, Strategi Pendidikan Islam, Jakarta: Erlangga, 2013

Muwahid Sulhan, Administrasi Pendidikan, Jakarta: Bina Ilmu, 2004

Sondang P. Siagian, Filsafat Administrasi, Jakarta: Gunung Agung, 1982

Stephen P Robbins,. Perilaku Organisasi, terj. Drs. Benyamin Molan, Jakarta : PT Index Kelompok Gramedia. 2006

Subana Sudrajat, Dasar-dasar Penelitian Ilmiah, Bandung: Pustaka Setia, 2001

Suratno Arsyad Lincoln, Metodologi Penelitian Untuk Ekonomi dan Bisnis, Yogyakarta: UPP AMPYKPN,1995 


\section{MEDIA505IAN}

Jurnal Ilmu Sosial dan Ilmu Administrasi Negara Vol. 2 No. 2

Sutrisno Hadi, Metodologi Research, Yogyakarta:

Andi Offset, 1990 